\title{
Hobbes Meets the Modern Business Corporation
}

\section{R.J.G. Claassen, Utrecht University}

Political theory today has expanded its scope to debate business corporations, conceiving of them as political actors, not (just) private actors in the market place. This article shows the continuing relevance of Thomas Hobbes's work for this debate. Hobbes is commonly treated as a defender of the so-called concession theory, which traces the legitimacy of corporations to their being chartered by sovereign state authorities for public purposes. This theory is widely judged to be anachronistic for contemporary business corporations, because these can now be freely formed, on the basis of private initiative. However, a close reading of the crucial passages in Hobbes's work reveals a more subtle view, which rejects this private/public dualism. Hobbes's reflections on the companies of merchants of his day provide room for business corporations' pursuit of private purposes, while keeping them embedded in a public framework of authority. Moreover, by criticizing the monopoly status of these companies, he opens up a way to integrate market failure arguments from modern economics into concession theory. The "neo-Hobbesian concession theory" emerging from this analysis shows how concession theory can accommodate private initiative and economic analysis, and thus be a relevant position in the debate about the modern business corporation.

Keywords: Thomas Hobbes, authorization, companies of merchants, business corporations, concession theory

I would like to thank audiences at the Technical University Munich's 2016 workshop, in particular David Ciepley, Lisa Herzog, Mark Reiff, Abraham Singer, and Christian Neuhäuser; the INSEEC Paris Workshop 2017, in particular Eric Orts, David Silver, Tom Wells, Rob Hughes, Sandrine Blanc, Nicholas Cornell, Amy Sepinwall, and Florian Wettstein; the World Interdisciplinary Network on Institutional Research (WINIR's) yearly 2017 conference, in particular Bas van Bavel, Ingrid Robeyns, and Jojanneke Vanderveen; and the Utrecht University's workshop 2018, in particular (in addition to those already mentioned above) Andreas Scherer, PierreYves Néron, Paddy Ireland, Michael Bennett, Yara al Salman, and Isabelle Ferraras. I also would like to thank Michael Bennett and Laurens van Apeldoorn for commenting on a previous version. I would like to thank the Dutch Research Council (NWO) for funding under grant no. 36020-390, and the European Research Council (ERC) under the European Union's Horizon 2020 research and innovation program (grant agreement No. 865165). Last but certainly not least, I thank the extremely engaging reviewers at this journal for their extensive comments, which made the essay much better.

Published online December 4, 2020. https://doi.org/10.1086/712231

Polity, volume 53, number 1 (January 2021), pp. 101-131. 0032-3497/2021/5301-0005\$10.00.

(C) 2021 Northeastern Political Science Association. All rights reserved. 
$\mathrm{T}$ oday's business corporations are politically salient organizations. The same was true, but in very different ways, of the empire-building trading companies in the 17 th century. ${ }^{1}$ While Hobbes witnessed the birth phases of the first incorporated trading companies, chartered as monopolies for limited purposes, we today inherit a legally highly developed corporate form and face the unrivalled power of multinational corporations operating on a global scale. Thus, while in both Hobbes's time and our own, questions arise about the legitimacy of corporate power and its relation to state authority, it is not self-evident that both worlds share enough to make Hobbes's view on business corporations interesting for contemporary debates. Nonetheless, this is exactly what I will argue in this article.

Hobbes's overall position is, on the one hand, to defend an absolutist theory of sovereign power (the Leviathan), and, on the other hand, to reject all competing claims arising from sub-state corporate powers as threats to this sovereign power. In his view such corporations are "subordinate bodies" whose legitimacy depends upon a valid grant from the sovereign. Such corporations should not become, in his famous words, like "worms in the entrayles of a natural man." ${ }^{2}$ Most commentators today discard this position as outdated, since Hobbes treats corporations as strictly public organizations, which friend and foe agree is inaccurate for today's business corporation. I aim to change this perception. I will argue that Hobbes's texts contain the theoretical resources to reconstruct a promising neo-Hobbesian theory of the modern business corporation. When properly spelled out, such a view of legitimate corporate power can revitalize the "concession theory" of corporations. ${ }^{3}$

I start with a brief outline of the contemporary debate in political theory around the status of business corporations. I then present Hobbes's theory of legitimate state authority, emphasizing his formal schema of representation, which is key to understanding corporate agency. Next, I apply this schema to the business corporation. Aggregate and real entity theories-the main rivals to concession theory-offer unconvincing answers to the question of who authorizes corporations to act. The

1. Philip Stern, The Company-State. Corporate Sovereignty and the Early Modern Foundations of the British Empire in India (Oxford: Oxford University Press, 2011).

2. Thomas Hobbes, Leviathan, ed. Richard Tuck (Cambridge: Cambridge University Press, 1991 [1651]), 230.

3. Pierre-Yves Néron, "Business and the Polis: What Does It Mean to See Corporations as Political Actors?," Journal of Business Ethics 94 (2010): 333-52; David Ciepley, "Beyond Public and Private: Toward a Political Theory of the Corporation," American Political Science Review 107 (2013): 139-58; Isabelle Ferreras, Firms as Political Entities: Saving Democracy through Economic Bicameralism (Cambridge: Cambridge University Press, 2017); and Abraham Singer, "The Corporation as a Relational Entity," Polity 49 (2017): 328-51. 
concession theory, which points to government as the authorizing party, may seem just as unconvincing. However, based on a close interpretation of key passages, I show how Hobbes's version of concession theory differs from the standard interpretation of this theory and provides an opening for allowing private gain as a motive for business while understanding the concession to be based on public purpose. This leads to a neo-Hobbesian interpretation of concession theory marked by two features: the simultaneous presence of private and public purpose, and the reinterpretation of wealth maximization as itself a public purpose. Monopoly is a violation of this wealth maximizing purpose.

While others have discussed Hobbes in relation to the legitimacy of sub-state corporations in general and the business corporation in particular, none have tried to make the case for seeing Hobbes as a concession theorist in the sense in which I present it here. ${ }^{4}$ This article makes two main contributions. First, this neo-Hobbesian theory contributes to contemporary debates about corporations, since it gives the concession theory a theoretically firmer basis: Hobbes's theory of representation and authorization help to make concession theory live up to the legitimacy demands of democratic theory. Second, Hobbes's openness to commercial purpose and critique of monopoly help to open up concession theory to economic analyses of market failure. In both respects, this article aims to build bridges between Hobbes's past and the present. In doing so, we need to tread carefully, as always when we use canonical authors for contemporary purposes, keeping in mind the historically different context in which someone like Hobbes wrote. But it would be a missed opportunity if we would shun this altogether.

\section{Competing Political Theories of the Corporation}

Contemporary scholars typically agree on the main features of the modern business corporation, but they diverge in their understanding of its nature, invoking three competing political/legal theories: concession theory, real entity theory, and

4. For the general applications, see David Runciman, Pluralism and the Personality of the State (Cambridge: Cambridge University Press, 1997); Henry Turner, The Corporate Commonwealth: Pluralism and Political Fictions in England, 1516-1651 (Chicago: University of Chicago Press, 2016). For the particular applications to business, see Mark Neocleous, Imagining the State (Philadelphia: Open University Press, 2003); Joshua Barkan, Corporate Sovereignty. Law and Government under Capitalism (Minneapolis: University of Minnesota Press, 2013); Daniel Greenwood, "The Semi-Sovereign Corporation," in Property and Sovereignty: Legal and Cultural Perspectives, ed. James Charles Smith (London: Routledge, 2013), 267-94; and Samuel Mansell, Capitalism, Corporations, and the Social Contract: A Critique of Stakeholder Theory (Cambridge: Cambridge University Press, 2013). 
aggregate theory. After describing the concept of the corporation, I will outline these three theories.

Corporations are separate legal persons, which can act in some ways like natural persons. They can hold property, make contracts, be liable for debts, etc. Their separate legal personality makes it possible for groups of natural persons to act effectively in a common capacity, without each individual having to be involved in all the group's actions. Business corporations are one special kind of corporation, characterized by two essential features:

First, modern business corporations have a set of economic privileges, which developed over time during the early modern era, in particular with the emergence of the Dutch and English East India trading companies. ${ }^{5}$ One of them is asset-lock in, the ability of corporations to attract capital that cannot be taken back by its owners. Shareholders own shares, which they can freely transfer to third parties (in the case of publicly held corporations), but they cannot demand a refund from the corporation. Another key privilege is the limited liability granted to shareholders: the fact that the creditors of the corporation cannot lay a claim on shareholders' personal wealth to get their debts repaid. A third privilege, entity-shielding, is the opposite of this. Creditors of shareholders cannot get their debts repaid by filing a claim against the corporation. These privileges are well established as essential features of the corporation in corporate law. ${ }^{6}$ They explain the attractiveness of the corporate form as an investment vehicle, spurring economic growth. This concentration of capital also leads to a concentration of power. Hence in a political theory of the corporation, the main role of referring to these privileges is to explain the incredible size and power of corporations. ${ }^{7}$

The second feature of the modern business corporation is freedom of incorporation. Before the 19th century, incorporation was reserved to corporations which served a public purpose. For example, in the British context, "Ordinary commercial ventures were considered to be unworthy of any such privilege, and were therefore supposed to compete with each other on a level playing field established

5. Giuseppe Dari-Mattiaci et al., "The Emergence of the Corporate Form," The Journal of Law, Economics, and Organization 33 (2017): 193-236.

6. Margaret Blair, "Locking in Capital: What Corporate Law Achieved for Business Organizers in the Nineteenth Century," UCLA Law Review 51 (2003): 387-455; Henry Hansmann, Reinier Kraakman, and Richard Squire, "Law and the Rise of the Firm," Harvard Law Review 119 (2005): 1333-1403; and Reinier Kraakman et al., The Anatomy of Corporate Law: A Comparative and Functional Approach, 2nd ed. (Oxford: Oxford University Press, 2009).

7. Ciepley, "Beyond Public and Private." The other main role of referencing these privileges in political theory, which is particular to concession theorists such as Ciepley, is to stress the governmental provenance of the corporation. 
by the common law of partnership." In the 19th century in the United States, Britain, and other countries, laws were passed that relieved potential incorporators from the obligation to ask permission-in a more than merely formal sense-for being incorporated. The act or charter of incorporation now can contain any purpose, as long as it is lawful. ${ }^{9}$ Under the new system, incorporation became a mere administrative formality. ${ }^{10}$

Three standard theories have been put forward in legal and political thought to understand and evaluate the contemporary business corporation: concession theory, real entity theory, and aggregate theory. According to concession theory, corporations are created by law. They only exist as "artificial persons" in the sense that without the law these groups would have no personality. The law prescribes their mandates, which need to refer to some public purpose. According to real entity theory, corporations do have a separate existence. Law merely recognizes the personality that already inheres in the group as it has formed between a collection of natural persons. According to aggregate theory, the corporation is best understood as an association wholly reducible to its members. Its separate legal personality is downplayed, in favor of a picture in which the corporation is merely a "nexus of contracts" between individuals. The long-standing debate between these three theories is addressed extensively elsewhere. ${ }^{11}$ As a summary statement, one could say the concession theory ties the existence and the legitimate operation of corporations

8. Paul Johnson, Making the Market: Victorian Origins of Corporate Capitalism (Cambridge: Cambridge University Press, 2010), 119; similarly, see William Roy, Socializing Capital: The Rise of the Large Industrial Corporation in America (Princeton, NJ: Princeton University Press, 1997), 41.

9. Lynn Stout, The Shareholder Value Myth (San Francisco: Berrett-Koehler Publishers, 2012), 28.

10. More precisely, this development included two separable things: 1 . the replacement of charters granted by legislatures with an administrative procedure on the initiative of the incorporators; 2. the application of corporate status to more and more lines of economic activity, until in the end it encompassed all ordinary businesses. In practice, these two things coincided, but in theory a wider scope of activity could have been reached by a more generous practice of legislated grants; or vice versa, the administrative procedure could have remained restricted to a smaller class of business. I thank a reviewer for this clarification.

11. For summary statements, see David Millon, "Theories of the Corporation," Duke Law Journal, 1990, 201-62; Ciepley, "Beyond Public and Private"; Eric Orts, Business Persons: A Legal Theory of the Firm (Oxford: Oxford University Press, 2013); and Singer, "The Corporation as a Relational Entity." Historical overviews of the fate of these doctrines are given in Reuven Avi-Yonah, "The Cyclical Transformations of the Corporate Form: A Historical Perspective on Corporate Social Responsibility," Delaware Journal of Corporate Law 30 (2005): 767-818; and Ron Harris, "The Transplantation of the Legal Discourse on Corporate Personality Theories: From German Codification to British Political Pluralism and American Big Business," Washington \& Lee Law Review 63 (2006): 1421-78. 
closely to public authority, while the aggregate theory ties them to the corporation's (private) members. The real entity theory occupies somewhat of a middle position by recognizing the corporation as an entity in its own right with an existence independent from both its constituent members and public authority.

Some authors have criticized the usefulness of these categories. ${ }^{12}$ They argue that the rights and duties ascribed to corporations should be argued on the merits, not by way of ontological classifications about the "essential nature" of the corporation. These critics also point out that each theory has been used to defend opposite results, a malleability that would make them virtually useless. Finally, critics point to the enormous variations within each of these camps and urge attention to specific authors. These objections may serve as important warning signals, but I do not think that they invalidate the use of these broader categories as long as we clearly define what we are talking about. I will look at one specific author, Thomas Hobbes, and argue that his writings can help strengthen the general pattern of argumentation characteristic of concession theory. In doing so, I will be careful in distinguishing ontological and normative claims. In the legal literature the litmus test of these theories is seen in their capacity to "make sense" of the legal provisions governing contemporary corporations. This legal use, which tests these theories for their descriptive adequacy, is not my focus. In political theory, the theories can be used as critical tools, with the possible outcome that if the (legal) reality of the contemporary business corporation fails to live up to the normative demands of the theory, reality needs to be reformed.

In the contemporary political theory debate, most authors are critical of the aggregate theory. This is unsurprising, since the wish to develop a political theory of the corporation is motivated by a rejection of the purely economic lens that inspires most uses of the aggregate theory, especially the nexus-of-contracts variants which have become dominant in economics over the last decades. ${ }^{13}$ A recurring objection against the aggregate theory is that its reduction of the corporation to a nexus of contracts means that it cannot explain the separate legal personality of corporations. This comes out most clearly in the feature of limited liability. If a corporation is really reducible to its members, and is nothing but a vehicle for the promotion of its members' interests, then shareholders (as its members) should be liable for the

12. John Dewey, "The Historic Background of Corporate Legal Personality," Yale Law Journal 35 (1929): 655-73.

13. Michael Jensen and William Meckling, "Theory of the Firm: Managerial Behavior, Agency Costs and Ownership Structure," Journal of Financial Economics 3 (1976): 305-60; and Frank Easterbrook and Daniel Fischel, The Economic Structure of Corporate Law (Cambridge: Harvard University Press, 1991). 
corporations' debts and/or torts. ${ }^{14}$ This leads to a dilemma for aggregate theories: they can be accused of opportunistically emphasizing corporate members when it comes to distributing the benefits of corporate activity, but emphasizing the corporation itself when it comes to shouldering the burdens. Critics of the aggregate theory want to have the corporation tied to a broader range of political or social interests. The big question is how to theorize this alternative.

Both real entity and concession theory reject the idea that corporations are a mere thin cover for the actions of their members. Recently several authors have adopted a renewed version of the concession theory. ${ }^{15}$ For example, David Ciepley claims that corporations are "franchise governments." According to him, even in an era of freedom of incorporation, corporations still have "governmental provenance." They remain necessarily bound to state approval, in two different ways. First, it is impossible or prohibitively costly to create some of the corporation's legal privileges through contract (in particularly liability for tort and entity shielding). ${ }^{16}$ Second, the management's authority over workers (internal jurisdictional authority) derives from the government-granted charter of incorporation which defines the office of the managers. ${ }^{17}$ From this perspective, Ciepley criticizes real entity theory because it "conflates medieval corporations with the business corporation." ${ }^{18}$ Even if it would be true that certain medieval corporations-like towns, monasteries, or universities-had a pre-state existence and were then, in a second instance, recognized by the state, business corporations cannot exist as such before state incorporation.

Others propose renewed versions of real entity theory. ${ }^{19}$ For example, Abraham Singer argues that where the state recognizes a separate group of $\mathrm{n}$ individuals in law, it must be seeing " $n+1$ persons." Both the individuals (n) and the new entity

14. The efficiency rationale for limited liability for debts and for torts is debated between aggregate theorists and their opponents. See Easterbrook and Fischel, The Economic Structure of Corporate Law, 40ff; Henry Hansmann and Reinier Kraakman, "Toward Unlimited Shareholder Liability for Corporate Torts," Yale Law Journal 100 (1991): 1879-1934; Abraham Singer, The Form of the Firm: A Normative Political Theory of the Corporation (Oxford: Oxford University Press, 2018), 182-86; and Orts, Business Persons, 134-73.

15. Joel Bakan, The Corporation: The Pathological Pursuit of Profit and Power (London: Free Press, 2004); Christopher McMahon, Public Capitalism: The Political Authority of Corporate Executives (Philadelphia: University of Pennsylvania Press, 2012); and Ciepley, "Beyond Public and Private."

16. Ciepley, "Beyond Public and Private," 145.

17. Ibid., 150.

18. Ibid., 155.

19. David Gindis, "From Fictions and Aggregates to Real Entities in the Theory of the Firm," Journal of Institutional Economics 5 (2009): 25-46; Orts, Business Persons; and Singer, "The Corporation as a Relational Entity." 
$(+1)$ must be given recognition when the state is bestowing legal personality on a firm. This new entity, Singer argues, must not be seen as a mystical metaphysical unity of persons (an objection often held against traditional entity theory). Instead, Singer builds upon modern transaction cost economics to show how firms come into existence when they are more efficient than the market to coordinate the labor inputs of cooperators in production. Firms "cultivate the kinds of relationships that are both efficient and unavailable on the open market." Singer therefore calls his updated version a "relational entity approach." ${ }^{20}$ From his relational theory, Singer argues that "the concession theory cannot effectively account for the economic aspects of the corporation, which is to say, why individuals continue to incorporate in a world where corporations are not foisted upon society by sovereigns, but open to individuals to create voluntarily." ${ }^{21}$ Modern corporations exist because individuals aim to reap welfare benefits that cannot be obtained without the corporate form.

Other contemporary defenders of real entity theory also criticize the tradition of concession theory as they conceive it as hopelessly anachronistic, in light of the historical achievement of freedom of incorporation. For example, Eric Orts argues that the concession theory "is too authoritarian with respect to the business enterprise. It may have appealed to ancient Roman emperors and old English monarchs, but in part exactly for this reason it conflicts with a contemporary viewpoint that accords basic respect to individual human rights, including positive freedoms of association and negative freedoms against arbitrary dispossession. ${ }^{22}$ Similarly, Stephen Bottomley argues that "concession theory places too much emphasis on the state's responsibility for control of corporations, leading to inappropriate command-control styles of corporate regulation and giving insufficient weight to the importance of private interests and concerns in forming and running corporations." ${ }^{23}$

In different ways, these authors stress the private basis of modern corporations against the public origins which the concession theory attributes to the corporation. Three points emerge. First, they agree with concession theorists that corporations are separate legal persons, and that the state and law are necessary to create corporations. But, second, they emphasize that the contemporary corporation is a private initiative that comes into being when it is legally recognized; it no longer is a concession, in the sense of a conscious governmental decision to give some particular

20. Singer, "The Corporation as a Relational Entity," 343.

21. Ibid., 341.

22. Orts, Business Persons, 21.

23. Stephen Bottomley, The Constitutional Corporation: Rethinking Corporate Governance (Aldershot, U.K.: Ashgate, 2007), 44. 
privilege away to only some specific party. ${ }^{24}$ Third, they argue that such a private system is normatively attractive, for reasons of freedom (Orts) or social welfare (Singer). This interpretation of concession theory, which sees it as denying the role of private initiative, I will call the "customary interpretation." Introducing a Hobbesian perspective addresses these concerns, as I will show in the subsequent sections.

\section{Hobbes's Theory of Representation}

Hobbes's view of corporations is firmly embedded in his general political theory. Indeed, Hobbes sees both the state and sub-state corporations as species of the genus "corporation." He uses a theory of corporate personality to explain both. Hence, I will now first explain this general theory and its application to the state. In the next section I will then show how he applies it to sub-state corporations like the companies of merchants of his day. ${ }^{25}$

Hobbes gives his account of personhood in chapter XVI of the Leviathan, where he distinguishes between natural and artificial persons. A natural person is someone "whose words or actions are considered ... his own." ${ }^{\text {"26 }}$ A natural person acts on their own behalf, or represents themself. By contrast, an artificial person is "representing the words or actions of another man, or of any other things to whom they are attributed, whether Truly or by Fiction." ${ }^{27}$ A natural person can authorize an artificial person to represent them. The first person Hobbes calls the "author";

24. A confusion between two different uses of the word "concession" looms large. The first marks off the position of one group (which gets the concession and becomes a corporation) from other groups who do not get this privilege. When incorporation loses its privileged character and everyone can start a business, obviously incorporation is no longer a concession in this sense. But it remains a concession in that 1) all those incorporated groups still have different (privileged) legal powers compared to individuals and partnerships in economic life, and 2) the government could not have conceded this; general incorporation was/is a political decision, which in principle could be reversed. I am interested in the latter sense of concession.

25. Hanna Pitkin, The Concept of Representation (Berkeley: University of California Press, 1967); David Copp, "Hobbes on Artificial Persons and Collective Actions," Philosophical Review 89 (1980): 579-606; Quentin Skinner, "Hobbes and the Purely Artificial Person of the State," Journal of Political Philosophy 7 (1999): 1-29; David Runciman, "Debate: What Kind of Person Is Hobbes's State? A Reply to Skinner," Journal of Political Philosophy 8 (2000): 268-78; Philip Pettit, Made with Words: Hobbes on Language, Mind, and Politics (Princeton, NJ: Princeton University Press, 2008); Monica Vieira, The Elements of Representation in Hobbes: Aesthetics, Theatre, Law, and Theology in the Construction of Hobbes's Theory of the State (Leiden/Boston: Brill, 2009); and Sean Fleming, "The Two Faces of Personhood: Hobbes, Corporate Agency and the Personality of the State," European Journal of Political Theory, at https://doi-org.proxy.library.uu.nl/10.1177 /1474885117731941 (2017).

26. Hobbes, Leviathan, 111.

27. Ibid. 
the second one the "actor." 28 The artificiality of the actor relates not to the fact that they are not a natural person (they are capable of representing themself as well), but to the fact that their words are not really "their own." They speak on behalf of someone else. The relation is one of authorization, and thus Hobbes recognizes that the artificial person now has "authority," or "the Right of doing any Action." 29 While the actor has the right, it is crucial for Hobbes that the responsibility of the action remains with the author. The actions are attributed to the author as if they were their own. They have to bear the consequences, positive or negative, of their actions. ${ }^{30}$ Attribution and authorization are two sides of the same coin.

A complication arises with "inanimate things," which includes physical structures ("a Church, an Hospital, a Bridge") and—to use a contemporary term-"marginal agents" ("Children, Fooles and mad-Men"). ${ }^{31}$ These have in common that they cannot authorize others to act on their behalf, since they lack reason. However, Hobbes argues that third parties-the "Owners, or Governours of those things," such as guardians or curators-can authorize representatives to do so. ${ }^{32}$ This introduces a three-place relation, between an author, an "inanimate thing," and a representative. The difference from the earlier two-place form of representation explains the use of the phrase "Truly or by Fiction" in Hobbes's definition of artificial persons. When an artificial person is authorized by a natural person, the representation is done "truly"; when they are representing an inanimate thing they are doing so by fiction. I will refer to them henceforth as fictional persons. ${ }^{33}$ Some of these fictional persons already existed before they were represented (bridges or mad men), while others only come into existence through the act of creating a representative, by their governors or owners (like the state). All of them become persons (i.e., bearers of status in the moral and/or legal community) by virtue of the act of being represented.

Hobbes's account of collective agency follows the same three-place schema. Hobbes's primary interest is the fictional person of the state. The state is created by an act of a multitude of men who make a covenant, stating to each other: "I Authorise and give up my Right of Governing my selfe, to this Man, or to this Assembly of Men, on this condition that thou give up thy Right to him, and Authorise all his Actions in like manner." ${ }^{4}$ This covenant simultaneously has two effects. First,

28. Ibid., 112.

29. Ibid.,

30. Pitkin, The Concept of Representation, 19.

31. Hobbes, Leviathan, 113.

32. Ibid.

33. Runciman calls them "persons by fiction"; see Runciman, "Debate: What Kind of Person Is Hobbes's State? A Reply to Skinner," 271.

34. Hobbes, Leviathan, 120. 


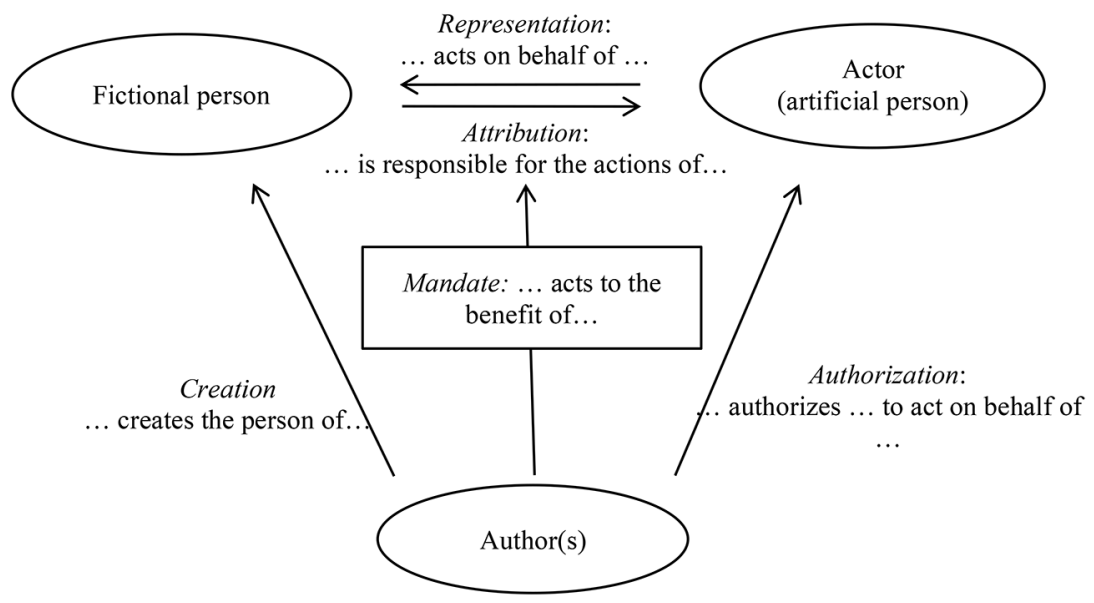

Figure 1. Hobbes's Theory of Authorization/Representation ${ }^{35}$

a sovereign is appointed, acting as the representative of the state. The sovereign (a single person or assembly) is an artificial person, who enables the state to act. Second, by appointing a sovereign, the covenant unites an otherwise dissociated group into a unity, a new person which Hobbes refers to as the "Commonwealth" or "State." This is the creation of a fictional person, analogous to the hospital. The two new persons are closely related: only by appointing a representative can there be the person of the state. This is not specific to the state, but holds for collective agents more generally. To come to life in social practice, they need a structure in which decision makers are appointed. The three persons-multitude, sovereign, and state-need to be kept strictly distinct. While the identity of members of the multitude as well as the identity of the sovereign may change over time (new natural persons are born into the multitude and older ones die), the identity of the state remains intact. It can in theory (but need not in practice) exist in perpetuity. The state has legal personality and can make contracts, wage war, and so on. The acts done on its behalf by its representative, the sovereign, are attributed to it. Hence authorization and attribution now come apart. While the multitude authorizes, the acts of the sovereign are attributed to the state (See figure 1 above).

Hobbes's account of personhood suggests both formal and substantive normative criteria by which to judge whether sovereigns are acting legitimately. ${ }^{36}$ The formal criterion is a valid act of authorization. Any act of representation needs a

35. Strikingly, I found a similar diagram (after constructing my own) in David Runciman, "Hobbes's Theory of Representation: Anti-Democratic or Proto-Democratic?," in Political Representation, ed. Ian Shapiro et al. (Cambridge: Cambridge University Press, 2010), 15-34.

36. Similarly, see Quentin Skinner, "A Genealogy of the Modern State," Proceedings of the British Academy 162 (2009): 348. 


\section{Hobbes Meets the Modern Business Corporation}

valid authorization of the actor by the author, and the state is no exception. The covenant between the members of the multitude fulfils this function. Here we find Hobbes's formulation of social contract theories' core idea, that the legitimacy of government derives from the consent of the people. However, Hobbes gives a particular twist to this idea, because he argues that authors have transferred their right to take actions to the actor that acts on their behalf. This comes with two duties: to accept the responsibilities that follow from the actors' deeds, and not to interfere with whatever the actor does. ${ }^{37}$ This right to act, since it is transferred to the sovereign, cannot be taken back unilaterally. Every citizen has authorized the sovereign to undertake actions on their behalf- "in the same manner, as if they were his own"38 - and must now accept that the sovereign acts in their name. From this strong form of authorization follow some of the more controversial aspects of Hobbes's theory, such as that the sovereign cannot commit an injustice to his subjects or that a criminal who is punished by a sovereign in some sense punishes himself. ${ }^{39}$

The substantive criterion lies in the mandate for which the actor is authorized. An act of the sovereign is legitimate when it does not overstep the mandate which is expressed in the contract. Hobbes argues the commonwealth is created "to the end he may use the strength and means of them all, as he shall think expedient, for their Peace and Common Defence." ${ }^{\prime 0}$ This particular (perhaps narrow) interpretation of the public interest expresses his overriding concern with the absence of physical security in the state of nature. It leads to an almost unlimited mandate, given Hobbes's description of the individual's right in the state of nature as a 'right to every thing." ${ }^{41}$ Whatever the substance of the mandate, this substance at the same time gives the criterion to judge whether the sovereign acts legitimately. Only where the sovereign's actions promote the public interest is it acting within the bounds of the established authorization relation. ${ }^{42}$

37. Skinner, "Hobbes and the Purely Artificial Person of the State," 26-27.

38. Hobbes, Leviathan, 121.

39. Ibid., 124 and 122.

40. Ibid., 121.

41. Ibid., 91.

42. The question is who is to judge whether the mandate is fulfilled. If the subjects are, then this reintroduces "private judgment" into Hobbes's theory. See Jean Hampton, Hobbes and the Social Contract Tradition (Cambridge: Cambridge University Press, 1996), 199. If the sovereign, then it seems difficult to explain why Hobbes would allow them a right of self-defense (which presupposes such a judgment). For this tension in Hobbes, see Hampton, 197-207; Michael Ridge, "Hobbesian Public Reason," Ethics 108 (1998): 538-68; and Shane Courtland, "Public Reason and the Hobbesian Dilemma," Hobbes Studies 20 (2007): 63-92. The more democratic iterations of Hobbes (see main text hereafter) do not suffer as much from this tension, since they allow for ongoing judgments by citizens about the rightness or wrongness of the sovereign's actions (the "third alternative," mentioned by Hampton, Hobbes and the Social Contract Tradition, 195. 
Despite Hobbes's own association with absolutism, his formal schema of representation remains a valid starting point for thinking about representation in democratic theory. Here I fully agree with David Runciman, who has forcefully argued this point. ${ }^{43}$ Hence, we can imagine more liberal formulations of the sovereign's mandate than Hobbes's-for example, where the protection of certain basic rights is made the subject of the social contract. Hobbes's schema shows there is no prepolitical unity of the collective; only through representation by a representative does the multitude of individuals acquire such a unity. The legitimacy of the new collective agent is dependent on authorization by the multitude. In more democratic iterations of Hobbes's schema, citizens' feedback about the performance of the representative in elections and public debates ensures its ongoing legitimacy. ${ }^{44}$

Hobbes's theory of representation has distinctive features compared to other theories of representation in political theory. I cannot go into this here, but will assume that Hobbes's theory of representation remains attractive as a basis for work in political theory. ${ }^{45}$ Hobbes's schema of the creation of collective agency is applicable not just to the state but to other fictional persons as well. ${ }^{46}$ In the next section, I explain how it applies to the business corporation.

43. Runciman in particular answers to Pitkin's influential criticism of Hobbes (in Pitkin, The Concept of Representation, 29-34), arguing that Hobbes's concepts "open up the possibility of a more democratic concept of representation. But as Hobbes uses them, that possibility is closed down." Runciman, "Hobbes's Theory of Representation," 24.

44. Runciman, "Hobbes's Theory of Representation," 26; here I use the term "social contract" widely, to denote all theories basing the legitimacy of the state on the consent of the people, regardless of the question whether "the people" do or do not exist as a pre-political unity that contracts with the sovereign (some prefer to reserve the term for the former type of theory only, so that Hobbes is not a social contract theorist).

45. Two issues in particular stand out. One is Hobbes's focus on representation as "acting-onbehalf of," instead of, for example, Michael Saward's account of representation as a depiction or "portraying-something-as-something"; see Michael Saward, The Representative Claim (Oxford: Oxford University Press, 2010). The other is Hobbes's constructivist understanding, where the identity of the represented is shaped in the act of representation. For a thoughtful discussion of both these elements, and further literature references, see Thomas Fossen, "Constructivism and the Logic of Political Representation," American Political Science Review 113 (2019): 824-37.

46. This is no coincidence, since Hobbes modelled his account of the state on medieval corporate theory, which was created for non-state corporations. See Vieira, The Elements of Representation in Hobbes, 160. Biographically, Hobbes's acquaintance with the joint-stock company may even have been at the origins of this corporate influence in Hobbes's account of the state; see Mathias Hein Jessen, "The State of the Companies: Corporations, Colonies and Companies in Leviathan," Journal of Intellectual History and Political Thought 1 (2012): 82; and Turner, The Corporate Commonwealth, 216. Given the structural similarity, one can call the state a corporation as well. See Eric Enlow, "The Corporate Conception of the State and the Origins of Limited Constitutional Government," Washington University Journal of Law and Policy 6 (2001): 128; and David Ciepley, "Is the US Government a Corporation? The Corporate Origins of 


\section{4 | Hobbes Meets the Modern Business Corporation}

\section{Application of Hobbes's Theory of Representation to the Business Corporation}

Taking business corporations as fictional persons under Hobbes's schema of representation raises the questions: who are the authors, and who the actors for the business corporation? ${ }^{47}$ Identifying the actor in the case of the corporation is quite easy. The actors are its board of directors, or whomever is legally entitled to represent the corporation in law. But who are the authors in a Hobbesian sense, those who authorize the actors to act on behalf of the corporation? This is a truly difficult question. In this section, I will first discuss some answers to this question systematically, and only then introduce Hobbes's own answer.

Based on the analogy with the social contract, one might think that the answer would be the founders of the corporation. However, the founders might be dead, while the corporation is still alive. The authorization relation need not be a single moment in time but can be a continuing relation-as in democratic interpretations of Hobbes's schema in which the members of the multitude change due to births and deaths while the commonwealth remains identical. At every moment in time, there must be a set of persons identifiable as the members of the commonwealth, for whom it exists and from whom its authority emerges; otherwise the commonwealth would be an empty body, a zombie collective. Similarly, the business corporation must rely on an underlying constituency that continues to animate the corporation. But who fulfils this role? The three theories of the corporation discussed earlier suggest different answers.

Aggregate theories suggest that shareholders count as the authors of the standard business corporation. In corporate law they are counted, for all practical purposes, as the owners of the corporation. ${ }^{48}$ Talk of corporations as "shareholder democracies" reinforces this point of view, in which shareholders take the role of authors, analogous to the role of citizens in a state. ${ }^{49}$ Hobbes's formal schema on its own does not exclude this possibility. As explained above, being the owner of a bridge or other object is one important way in which one can become author. However, this line of interpretation also raises problems. First, it is dubious to describe shareholders as owners of the corporation. The shareholders hold shares, but

\footnotetext{
Modern Constitutionalism," American Political Science Review 111 (2017): 418-35. However, not to confuse matters, I will reserve the term corporation for non-state corporations.

47. Mansell, Capitalism, Corporations, and the Social Contract, 107.

48. Kraakman et al., The Anatomy of Corporate Law, 14.

49. Mark Freeman, Robin Pearson, and James Taylor, Shareholder Democracies? Corporate Governance in Britain and Ireland before 1850 (Chicago: University of Chicago Press, 2012).
} 
this gives them no direct control rights over the corporation's assets. The corporation owns assets in its own name and is a legal person not itself owned by anyone. Control over the assets lies with the board of the corporation..$^{50}$ Here again the aggregate theory doesn't take the personality of the corporation sufficiently seriously. Advocates of aggregate theory might argue that this is formalistic hair-splitting. We could interpret the control rights shareholders have (i.e., to elect the board) as giving "control over the corporation" as a whole, and thus also over the corporate assets. After all, by electing the board, shareholders can influence corporate policy considerably. But this argument faces a second problem, which Strudler points out by drawing an analogy with non-profits: A non-profit organization like a hospital is controlled by its directors, but the directors do not own the hospital. The hospital organization is unowned. Conclusions about control thus do not generate conclusions about ownership. ${ }^{51}$

An alternative would be to claim that shareholders, while not owners, should count as the members of the corporation, analogous again to citizens in a state, or private members in an association (like the local football club). Authorship then comes through membership, not ownership. I cannot provide a longer discussion here about the appropriateness of the term "member" as applied to shareholders. ${ }^{52}$ But even if one would think this term applicable, this would not vindicate the special position for shareholders that aggregate theorists are looking for, because such membership would have to be deserved on account of some feature; call it having an "interest" or a "stake" in the flourishing of the corporation. That feature could then also be applied to other stakeholders of the corporation, who also have an interest in its flourishing (e.g., employees). If corporations have members, surely (some) other parties besides shareholders should deserve membership status too. ${ }^{53}$

50. Stout, The Shareholder Value Myth; Orts, Business Persons; David Ciepley, "The AngloAmerican Misconception of Stockholders as 'Owners' and 'Members': Its Origins and Consequences," Journal of Institutional Economics, at https://doi.org/doi-org/10.1017/S1744137419000420.

51. Alan Strudler, "What to Do with Corporate Wealth?," Journal of Political Philosophy 25 (2017): 115.

52. I am inclined to follow Ciepley, in saying that business corporations are not member corporations, but so-called property corporations. This feature they share with foundations (but not associations); and herein lies the problem of their authorship. See David Ciepley, "Member Corporations, Property Corporations, and Constitutional Rights," Law \& Ethics of Human Rights 11 (2017): 31-59; and "The Anglo-American Misconception."

53. These passages should not be read as a refutation of the aggregate theory; such a refutation hinges on the question whether one thinks the aggregate theory can account for the abstract legal personality of the business corporation (see section 1). Here I only focused on the question of which party, if one were to accept aggregate theory, would be the author in Hobbes's sense; and I tried to show that "the shareholder" would not be a convincing answer. 


\section{6}

\section{Hobbes Meets the Modern Business Corporation}

Real entity theories, as we saw, do more justice to the abstract character of the corporation than do aggregate theories. If one wants to think about legitimacy in terms of author-agency relationships, then from a real entity perspective the corporation itself should be seen as its own author. ${ }^{54}$ Managers should act as agents of the corporation. Such a point of view surely takes seriously the separate personality of the corporation..$^{55}$ Aggregate theorists criticize this position for giving directors a free hand to abuse their power under the cloak of furthering the interests of the corporation. A Hobbesian criticism would be different; it would point out the ontological impossibility of ascribing an authorial role to the corporation itself, for the representative schema serves to create corporations as fictional persons, which mediate between authors and agents. The whole point of Hobbes's innovative theory of representation is to show how fictional persons cannot act on their own; they need representatives to be brought to life. We can here adopt Frederic Maitland's words: "Were the corporation 'itself' capable of appointing an agent, there would be no apparent reason why 'itself' should not do many other acts." ${ }^{56}$ In terms of normative theory, the real entity perspective allows the legitimacy of corporate actions by representatives to hang in the air, since there is no author to which they are held accountable. ${ }^{57}$

Hobbes's own view of non-state collective agents can be found in chapter XXII of Leviathan. Here he distinguishes two types of collective agents (which he called "regular systems"): absolute or independent ones and dependent or subordinated ones. The first type only refers to the state (commonwealth). All other collective agents are "Subordinate to some Soveraign Power." ${ }^{38}$ Hobbes divides these subordinate systems into political ones ("Bodies Politique") and private ones. On private

54. Singer, The Form of the Firm, 179.

55. The "business judgment rule" says that courts will not second-guess managers' decisions, even when they seem to harm shareholders; see Stout, The Shareholder Value Myth, 2931. Stout takes the existence of this rule as also providing an argument that managers are in their right when they do not focus on shareholder value maximization (i.e., do not follow aggregate theory). The rule relies on the construction of an independent interest of the corporation itself, separately from its shareholders.

56. Frederic Maitland, "Translator's Introduction," Political Theories of the Middle Age, by Otto Gierke (Mansfield Centre, CT: Martino Publishing, 2014), xx.

57. More precisely, from a Hobbesian perspective, real entity theory presupposes that corporations, like natural persons, are self-representing and self-authorizing persons. See Vieira, The Elements of Representation in Hobbes, 84-89. In contrast to the case of natural persons, for corporations this is a problematic assumption-or so Runciman argues, convincingly to my mind. See Runciman, Pluralism and the Personality of the State, 238-43.

58. Hobbes, Leviathan, 155. 
bodies, Hobbes is relatively brief. Their essential characteristic is that they are "constituted by Subjects amongst themselves," 59 or again "constituted without Letters, or other written Authority." ${ }^{60}$ The only example Hobbes mentions is the family, represented by the father. As to political bodies, Hobbes says that their power is always limited by the power of the Sovereign. These limits are given by two sources: "their Writt, or Letters from the Soveraign" and the "Law of the Common-wealth." 1 Hobbes emphasizes that all acts of such political bodies are "the act of everyone"in other words, every citizen in society. ${ }^{62}$ This he explicitly justifies through a twostep process of authorization: all citizens have authorized the sovereign, and the sovereign has authorized (through the Letters and/or the Law) the specific political body. As examples of political bodies he names provinces, colonies, towns, universities, colleges, and churches, but also companies of merchants. The classification of companies of merchants as political bodies conforms to the status of the rising trade companies in his own time, which were chartered by governments to exploit trade overseas with the colonies. I will return to what precisely Hobbes says about them below.

In chapter XXIX, Hobbes discusses things that may weaken a Commonwealth. Here he explicitly lists "the great number of corporations" as a danger, and we find the famous passage about corporations as "many lesser Common-wealths in the bowels of a greater, like wormes in the entrayles of a natural man." ${ }^{63}$ Corporate power may challenge and threaten the absolute power of the sovereign, acting, in Greenwood's contemporary use of Hobbes, as "Semi-Sovereign Corporations." 64 Or, in Barkan's words: "Corporations could lead to divided sovereignty or, worse, a state within a state, imperium in imperio." ${ }^{55}$ The passage in chapter XXIX does not, strictly speaking, add anything to the legitimacy conditions mentioned above, but it does testify to the enormous suspicion Hobbes entertained against any powerful group acting as a rival to the Sovereign. He held a similar suspicion for the Catholic church, the universities, and other corporate entities. ${ }^{66}$

59. Ibid.

60. Ibid., 162.

61. Ibid., 156.

62. Ibid.

63. Ibid., 230.

64. Greenwood, "The Semi-Sovereign Corporation," 280.

65. Barkan, Corporate Sovereignty, 35.

66. Richard Boyd, "Thomas Hobbes and the Perils of Pluralism," Journal of Politics 63 (2001): 392-413; Vieira, The Elements of Representation in Hobbes, 193; and Turner, Corporate Commonwealth, 250. 
Hobbes seems to be a clear representative of the concession or grant theory, since corporations depend, in his view, on the authority of the Sovereign for their existence. All the important elements of the concession theory are present. First, corporations, like all collective agents (the state included), are fictional persons in Hobbes's theory of representation. Indeed, it was Hobbes's leading innovation to distinguish the fictitious person of the state from the real persons of the ruler and the ruled. ${ }^{67}$ This fictitious nature characterizes corporations as well. ${ }^{68}$ Second, the existence of the corporate person depends on a concession from the government-in Hobbes, the concession is formulated in the "Letters from the Sovereign," while today it is called the act or charter of incorporation. Genealogically, corporations are created by governmental initiative. ${ }^{69}$ Third, the legitimacy of corporate action is bound to the instructions and/or limits set upon the corporation by the sovereign. Thus, a continuous bond to public authority after its creation ensures that corporations can become no danger to the public at large. They are inserted in a chain of public authority guaranteeing that they fulfil a public purpose. Taken together, Hobbes's place in the concession theory camp seems undisputed.

For a contemporary use of Hobbes, this may be thought to be exactly the problem, because the concession theory's public purpose orientation completely misses out on the modern business corporation's private character. A Hobbesian can respond in two ways to such criticisms. The first and more radical route would be to say: well, too bad for the modern business corporation. The concession theory is a normative theory. If the concession theory does not describe the modern business corporation accurately, this is because economic and legal realities in our societies have developed in a direction which has ignored the prescriptions of concession theory. This response would, however, defend a premodern practice where only

67. Skinner, "A Genealogy of the Modern State."

68. Historically, the "fiction theory" is often treated as separate, but connected to, the "concession theory" (the former being about the ontology of corporations, the latter about their legitimacy). Logically, the latter implies the former but not vice versa. See Runciman, Pluralism and the Personality of the State, 108-09. From my overview, I construe the fiction theory as the first of the three elements of the concession theory. In fact, the fictional element does not, in my view, contain a terribly controversial statement, as long as one keeps in mind that fictions are very real in their consequences. Here I concur with Orts, Business Persons, 16. The real issue is about the nature and justification of the other two elements outlined here.

69. Both Runciman and Vieira point out the closeness of Hobbes to concession theory. See Runciman, Pluralism and the Personality of the State, 28; and Vieira, The Elements of Representation in Hobbes, 196. However, both also point out how Hobbes allows "irregular" (unlawful) groups to come into existence outside of the state. See Runciman, Pluralism and the Personality of the State, 31; and Vieira, The Elements of Representation in Hobbes, 198. "Existence" for the concession theory is about lawful existence; and the latter requires state action. 
a very limited set of government-chartered corporations could legitimately exist. This would do away with the advantages in terms of economies of scale in production that corporations have brought to capitalist economies over the last centuries. More importantly, I argue that this reasoning does not interpret Hobbes as accurately as the second possible response, which is to see the public concession as compatible with private initiative.

\section{Hobbes on the Trading Companies}

I argue that it is possible to discern a neo-Hobbesian position, which starts from Hobbes's theory of representation and reaches the familiar Hobbesian conclusion that corporations should be seen as publicly authorized and treated with suspicion as soon as they (acquire the powers to) turn against the Sovereign. However, it reaches that conclusion through an analysis of corporate purpose as public, but also private, and hence compatible with the features of the modern business corporation stated above-most notably, freedom of incorporation. The reconciliation of these apparently contradictory theses offers a credible contemporary concession theory whose crucial elements can be traced to Hobbes's own analysis of the merchant companies of his time.

To establish this neo-Hobbesian position, I begin with two crucial passages in Hobbes's Leviathan: his analysis of the act of concession and his analysis of the merchant companies. ${ }^{70}$ The first passage, about the act of concession, appears at the start of chapter XXII:

The bounds of that Power, which is given to the Representative of a Bodie Politique, are to be taken notice of, from two things. One is their Writ, or Letters from the Soveraign: the other is the Law of the Common-wealth.

For though in the Institution or Acquisition of a Common-wealth, which is independent, there needs no Writing, because the Power of the Representative has there no other bounds, but such as are set out by the unwritten Law of Nature; yet in subordinate bodies, there are such diversities of Limitation necessary, concerning their businesses, times, and places, as can neither be

70. Corporations are also mentioned in his two other political works, but the treatment in Leviathan is the most substantive and the other works foreshadow and confirm his account therein. See chapters 19.9 and 27.7 of Thomas Hobbes, Elements of Law Natural and Political, ed. J.C.A. Gaskin (Oxford: Oxford University Press, 1999 [1640]). And see chapter 5.10 of Thomas Hobbes, On the Citizen, ed. Richard Tuck and Michael Silverthorne (Cambridge: Cambridge University Press, 1998 [1642]). 
remembered without Letters, nor taken notice of, unless such Letters be Patent, that they may be read to them, and withal sealed, or testified, with the Seales, or other permanent signes of the Authority Soveraign.

And because such Limitation is not alwaies easie, or perhaps possible to be described in writing; the ordinary Lawes, common to all Subjects, must determine, what the Representative may lawfully do, in all Cases, where the Letters themselves are silent. ${ }^{71}$

David Runciman interprets this passage to drive a wedge between Hobbes and the standard medieval concession theory. Whereas the latter merely recognized one mode of concession-namely, an explicit charter-Runciman claims that Hobbes recognizes two modes of concession: by charter, or by general law. Some corporations, in this view, can be authorized without an explicit act of concession directed at the new corporation-to-be. ${ }^{72}$ This is a problematic interpretation of the passage above, for two reasons. First of all, this passage is about the limitations set upon representatives of the corporation, not about the act of creating these corporations in the first place, which makes it hard to derive any hard conclusions from it about Hobbes's thoughts on their lawful creation. Second, the passage explicitly puts the Letters from the Sovereign at the forefront of defining these limitations. General laws only come in at the point where there are situations which one cannot easily or possibly describe "in writing." Nowhere does Hobbes suggest that this is a separate mode of creating corporations. ${ }^{73}$ Nor is this suggested by his general description, earlier in the chapter, of bodies politique as "made by authority from the Sovereign Power of the Common-wealth" - which suggests, if anything, an explicit act of concession. So far, then, Hobbes seems to offer a traditional interpretation of concession theory. ${ }^{74}$ If there is a difference between Hobbes's interpretation and what I called "the customary interpretation," it is not where Runciman locates it, in the absence of a requirement of an explicitly written charter. We must search for it elsewhere.

71. Hobbes, Leviathan, 156.

72. Runciman, Pluralism and the Personality of the State, 28, 49, 93.

73. This interpretation is confirmed in two other passages, which suggest a bifurcation between explicit letters and general laws, namely, those on the companies of merchants ("any other law, than that which is common to all other subjects," at 160) and on private bodies ("constituted without Letters, or other written Authority, saving the Lawes common to all other subjects," at 162).

74. Although Hobbes does not have anything to say about the particular legal features of the corporation discussed in the first section, he emphasizes the liberties that come with Sovereign charters as exemptions from normal law. See Hobbes, Leviathan, 200. See also the discussion in Barkan, Corporate Sovereignty, 37. 
Because the passage above focuses on the limitations of the power of representatives, it does not make clear the positive rationale-the purpose-for which Sovereigns create corporations. The first thing Hobbes notes is that they can be created for a variety of purposes:

The variety of Bodies Politique, is almost infinite: for they are not onely distinguished by the severall affaires, for which they are constituted, wherein there is an unspeakable diversitie: but also by the times, places, and number, subject to many limitations. ${ }^{75}$

Second, when he then comes to speak of the Companies of Merchants, Hobbes explicitly claims that the aim of this is private. He states:

The End of Incorporating, is to make their gaine [i.e. that of the merchants] the greater. ${ }^{76}$

Similarly, he states that

The End then of these Bodies of [Merchants], being not a Common benefit to the whole Body, . . . but the particular gaine of every adventurer. ${ }^{77}$

There could be no clearer statement on Hobbes's part that corporations can have a private purpose, at least as seen from the individual perspective of those who wish to incorporate. Apparently, such private purposes do not themselves stand in the way of incorporation. At this point, it should be kept in mind that the companies of merchants developed as "regulated companies," and that they resemble modern business corporations only in a limited sense. The role of merchants can be described as that of members who regulated their behavior through the corporation's imposition of a common set of rules. At the same time, the merchants traded with their own capital and on their own account-all of this as in a guild. ${ }^{78}$ Hobbes acknowledges their private purpose when talking about their "gaine" as their reason for incorporating.

75. Hobbes, Leviathan, 158.

76. Ibid., 160.

77. Ibid., 161.

78. Ciepley, "The Anglo-American Misconception," 10. The regulated company should not be confused, as Ciepley argues, with the joint stock company of these days, which is not a corporation. This is a specific, temporary collaboration of several merchants for the duration of one voyage, organized not as a corporation but as a partnership. See Ciepley, 14. Hobbes also talks about these, to distinguish them from the company of merchants. The passage ending with "But this is no Body Politique" hence treats both. See Hobbes, Leviathan, 160. 
Finally, that Hobbes is open to private purpose is even more explicit in the disjunctive statement in his Elements of Law, that defines corporations in general as

a subordinate union of certain men, for certain common actions to be done

by those men for some common benefit of theirs, or of the whole city. ${ }^{79}$

This sounds like a surprisingly modern viewpoint, much closer to the contemporary business corporations after freedom of incorporation than to the customary interpretation of concession theory; in the next section I will develop this point further. However, here I would note that this is only one side of the coin. The other side is that Hobbes simultaneously introduces the role of public purpose in his discussion of the companies of merchants. To complicate matters, he does so in two different senses. Hobbes himself lays no emphasis on the differences, but I will, here and in the next section.

First, Hobbes starts off his discussion of the companies of merchants as bodies politique by mentioning that they are "for the well ordering of forraigne Traffique." ${ }^{80}$ In his discussion of bodies politique in chapter XXII, the companies of merchants are presented as the second of three classes. The first class consists of bodies politique "for Government," like the government of a colony or a province." ${ }^{81}$ The third class is formed by temporary advisory counsels to the sovereign. ${ }^{82}$ When recapping the first two categories, Hobbes refers to them as "Bodies made for the government of Men, or of Traffique." ${ }^{\prime 3}$ This formulation nicely captures the point that the merchant companies are, as much as the first category, governmental. In practice, this went well beyond regulating trade in the narrow sense. All of this is familiar from the larger history of the trading companies. For example, the East India Company was chartered to "establish fortifications, make law, erect courts, issue punishments, coin money, conduct diplomacy, wage war, arrest English subjects, and plant colonies." ${ }^{84}$ Hobbes does not expand on the governmental tasks of the companies of merchants, but it is clear he recognized them.

Second, Hobbes talks more elaborately about the economic aspect of the companies of merchants. He tells us that they possess a double monopoly in selling and buying, both at home and abroad. He criticizes this monopoly for not being maximally profitable for the Common-wealth:

79. Hobbes, Elements of Law Natural and Political, sect. 19.9.

80. Hobbes, Leviathan, 160.

81. Ibid., 158.

82. Ibid., 162.

83. Ibid., 162.

84. Stern, The Company-State, 12. 
Of this double Monopoly one part is disadvantageous to the people at home, the other to forraigners. For at home by their sole exportation they set what price they please on the husbandry, and handyworks of the people; and by the sole importation, what price they please on all foraign commodities the people have need of; both which are ill for the people. . . . Such Corporations therefore are no other then Monopolies; though they would be very profitable for a Common-wealth, if being bound up into one body in forraigne Markets they were at liberty at home, every man to buy, and sell at what price he could. ${ }^{85}$

While Hobbes does not explicitly declare the monopolistic character of the companies of merchants to be sufficient reason to abolish them, he clearly does introduce in this passage a public point of view: the profitability of the company for the commonwealth as a whole. This is a public purpose which is internally connected to the private purpose of this specific type of corporation-namely, the profitability of the merchants themselves. Private citizens may strive to attain their private profits, but only in such a way that it is compatible with the profitability of the commonwealth. The latter concern introduces a specific angle to look at the legitimacy of these corporations, which is additional to the general requirements of public law which hold for all citizens.

So far, the textual analysis has shown us that Hobbes recognized the private purposes of the merchant incorporators, but that he recognized two types of public purposes for the companies of merchants as well. In the next section I will explain how this opens up an interpretation of concession theory which is useful for contemporary analysis.

\section{Outlines of the Neo-Hobbesian Concession Theory}

Hobbes offers a non-customary interpretation of concession theory, which defends what I call a "specific compatibility requirement." When it grants incorporation, the state allows corporations to have private purposes, but requires that these purposes should be compatible with a specific public purpose. He suggests a particular content for this public purpose in the case of commercial corporations: to create social wealth. As I explain in this section, this makes his theory compatible with the role of the corporation in the economy in the era after the freedom of incorporation.

85. Hobbes, Leviathan, 161. The critique of monopoly is repeated later, in chapter XXIX, at 229 , in more vehement terms. 
First, a Hobbesian interpretation of concession theory can best be described as an intermediary between the way the concession theory is customarily interpreted on the one hand, and the real entity and aggregate theories on the other hand. The customary interpretation of concession theory defends a public purpose requirement: the corporation is created to fulfil a specific public purpose $x$, where $x$ is defined by the Sovereign in the act of incorporation. The real entity and aggregate theories defend a general public compatibility requirement: the corporation is created to fulfil any private purpose $y$, but under the condition that it operates within the general bounds $z$ defined by the general (public) laws.

The second option clearly is not what Hobbes has in mind, and since the aggregate and real entity theories are inventions of the 19th century, this should not be a surprise. This option simply requires that corporations obey the laws of the land, like all individual citizens should. For example, it is a general public purpose, enforced through criminal law, that corporate representatives, like other citizens, do not murder. If this would suffice for corporate legitimacy, then public letters would hardly be required; we could simply place all corporations in the category of private bodies, operating without preceding public authorization. The first option, however, also does not fit Hobbes's description of the companies of merchants, and corporations in general. As we saw, Hobbes clearly recognizes they can have private purposes. As a model for the first category, we should take current-day public organizations, like municipalities (e.g., the City of Paris), regulatory agencies (e.g., the German Bundeskartellamt), and state-owned enterprises (e.g., the British Broadcasting Corporation). Our understanding today is that these are established at the initiative of government, for public purposes only. They simply would not exist were it not for the government judging that a certain job needed to be done. Of course, individuals working in these institutions may derive private satisfaction from their jobs, as may any employee, but that hardly counts as infusing these institutions with private purpose. The pre-modern understanding of corporations was more mixed, however, with towns, guilds, universities and other corporations seeking to get concessions from the central government (Crown), on their initiative, by claiming they represented also a public purpose. Hobbes expresses this understanding.

The Hobbesian interpretation of concession theory is thus an intermediate form of argument between the customary interpretation of concession theory and the real entity and aggregate theories. It defends a specific public compatibility requirement: a corporation can be created to fulfill a private purpose $y$, as long as it simultaneously fulfills a specific public purpose $x$, as defined by either the act of incorporation or by general laws. 
By accepting this combination of private and public purposes, Hobbes expresses the understanding of his times. In practice, Medieval and early modern monks, town elites, and university professors asking for a concession did so on their initiative, for a purpose (city government, spiritual salvation, higher learning) they deemed worthwhile pursuing themselves; call it "private purpose." By getting corporate status from the government, they were aiming at their own view of what was good. In that sense they are no different from contemporary businessmen. When critics attack the concession theory as anachronistic, they attack the customary interpretation. But actual historical practice always allowed for private initiative. Incorporation was to the benefit of both the private parties seeking it and the sovereign conceding it—and one can rightfully ask in each case who benefited most. ${ }^{86}$ This raises the intriguing question of whether anyone actually defended what is called here "the customary interpretation," or whether this is a straw man: a projection of contemporary, clearly public organizations (see examples above) onto the wide variety of corporations in Medieval and early modern times. The usual criticism of concession theory goes something like this: before the nineteenth century a public purpose was required for business corporations, but nowadays this is no longer true of them. Hence the concession theory is now false for them. But if throughout the centuries public purpose was always combined with private purpose, then this critique defeats a target that never existed. This has important consequences for the contemporary debate. A concession theory in which incorporation for ordinary commercial business activities is tied to a specific public purpose requirement may be a vital application of the general template of concession theory.

Hobbes's second contribution is that he served as a frontrunner for the recognition of social wealth creation as this public purpose. Hobbes's discussion of the merchant companies can be seen as a precursor of the historical movement in which governments were more easily prepared to see public value "within" (or intertwined with) the commercial purposes put before them. During the 19th century,

86. Greenwood argues that this grant of a piece of sovereign authority to specific groups is an essentially feudal characteristic of corporate law, which survives today. See Daniel Greenwood, "Neofeudalism: The Surprising Foundations of Corporate Constitutional Rights," University of Illinois Law Review 2017 (2017): 163-222. This interpretation stresses the loss of power of the sovereign under a concession system to private groups, not the empowerment of the sovereign, who uses corporations as an "extension" of government. Whatever of that, this interpretation shows how private initiative is an integral part of concession practice from the (feudal) start. See also Barkan, Corporate Sovereignty, 28-35. He stresses how states from the 16th century onwards increasingly used corporations to regulate social life, but did so by using citizens' "greedy appetite"; at 34 . 
incorporation was opened not just to single entities (holding a monopoly), but to specific lines of activity (banking, insurance, railroads, etc.). Later, it was opened to any commercial activity whatsoever. We saw above that Hobbes recognized that the companies of merchants fulfilled two public purposes: a governmental or regulatory purpose (the well ordering of foreign trade) and an economic purpose (the profitability of the Commonwealth). The former was uncontroversial, in his time. With the latter he introduces an element which would be very important in later centuries: the infusion of economic activity with public purpose.

Hobbes acknowledges that the trading companies in the monopolistic form they took in his day were problematic, but at the same time he accepts there can in principle exist an economic form of the corporation which would be in the legitimate interest of the commonwealth. This implies that the orientation to private gain can be compatible with the status of a political body, under the right (non-monopolistic) economic conditions. In contemporary terms, even commercially operating businesses contribute to the public purpose of the maximization of social wealth. This term is recognized to be the corporate purpose in the most prominent handbook of corporate law. ${ }^{87}$ Hobbes's analysis at this point prefigures the debate in economic theory started by Mandeville and Adam Smith in the eighteenth century when they characterized the market sphere as one where "private interests" (Smith) or even "private vices" (Mandeville) could lead to "public benefits." The underlying view is one where the market sphere is an organized competition commissioned by government to procure consumer goods at maximally competitive prices. Private parties are being used for such procurement, but this doesn't make the market less of a public space. Just as Roman authorities organized a competition between gladiators because they considered such a competition a public good ("bread and games") for the Roman people, so market competition is created to maximize the public good of social wealth.

In this line of thought, the current laws granting freedom of incorporation do contain a public mandate, even though they do not state it explicitly: to maximize social wealth. This is consistent with the description of Alfred Chandler, who explains the emergence of large business corporations as a response to newly created possibilities for economies of scale in production ${ }^{88}$; or with the reconstruction of North, Wallis, and Weingast, who argue that freedom of incorporation

87. Kraakman et al., The Anatomy of Corporate Law, 28.

88. Alfred D. Chandler Jr., The Visible Hand: The Managerial Revolution in American Business (Cambridge, MA: The Belknap Press, 1977). 
was crucial to establish open-access economic orders. ${ }^{89}$ Historical interpretations such as these reconstruct a general public purpose (realizing economies of scale, or open access orders) as lying behind the general incorporation laws of the nineteenth century, which were still confined to particular lines of activity, hence specific public purposes. This general public purpose was then assumed to be present in any economic activity in this line and, in the twentieth century incorporation, in any legally allowed activity whatsoever.

Hobbes's criticism of the merchants' monopoly status, which was also shared by Adam Smith and other classical authors, can be seen as a market failure argument avant la lettre. ${ }^{90}$ A perfect alignment of private incentive with social wealth maximization is not self-evident. As soon as market failures occur, the link is broken, and private vice mainly benefits private actors themselves, not the public at large. For example, Hobbes recognized that the absence of competition at home, which the companies of merchants enjoy due to their monopoly status, is not in the public interest-after all, imperfect competition is a prominent category of market failure. The neo-Hobbesian theory may therefore be considered a cousin of the market failure theory of business ethics. This theory criticizes corporations as a matter of moral judgment when, in situations of market failure, they put their private gain ahead of social wealth maximization. ${ }^{91}$ Where the institutional set-up does not ensure that private and social purpose automatically align (e.g., where anti-trust laws are insufficiently powerful to guarantee competition), individual actors acquire a moral responsibility not to abuse the situation. Here private actors should more directly take on the public purpose. However, Hobbes's criticism of monopoly suggests a more political twist. His point was that monopoly itself was granted by the Sovereign. Hence market failure in this instance was not a matter of unfortunate by-product, but of political will. Market failure was created by the institutional rules themselves of his time.

89. Dougless North, John Wallis, and Barry Weingast, Violence and Social Orders (Cambridge: Cambridge University Press, 2009), 211-13. A more critical historical analysis may reveal intense lobbying for these laws, inspired by opportunities for enhancing private wealth. See Roy, Socializing Capital. The Rise of the Large Industrial Corporation in America; and Paddy Ireland, "Limited Liability, Shareholder Rights and the Problem of Corporate Irresponsibility," Cambridge Journal of Economics 34 (2010): 837-56. This is not inconsistent with the story told here, since private and social wealth may come apart-indeed that is the whole point of the further analysis.

90. Adam Smith, An Inquiry into the Nature and Causes of the Wealth of Nations (New York: The Modern Library, 1994 [1776]), 814-15. For others, see overview in Johnson, Making the Market.

91. Joseph Heath, Morality, Competition and the Firm: The Market Failures Approach to Business Ethics (Oxford: Oxford University Press, 2014). 
This insight can be extrapolated beyond the specific problem of monopolies. Similarly, the rules of corporate law (the economic privileges) may produce market failures themselves (that the market theory of business ethics asks them in a second step not to exploit), in the sense that the power acquired by these privileges granted by the state (and that could not be acquired otherwise) provides large corporations with the means to impose negative externalities on others, create barriers to entry, charge monopoly prices, and so on. Corporations hence get an ambiguous mandate from the contemporary state. On the one hand, they get the freedom to pursue private wealth, in the interest of social wealth creation, mediated through the adversarial structure of market competition..$^{92}$ On the other hand, they get economic privileges that boost their size and power and enable them to produce market failures, which cancel the link between private and social wealth. It is this ambiguous situation that the institutional features of the business corporation bring to the table, and that the neo-Hobbesian analysis criticizes. In doing so, it makes use of a conception of public purpose that cannot be criticized as anachronistic (by pointing out that corporations now have freedom of corporation). Indeed, seeing the rationale behind freedom of incorporation means seeing how corporations have such a public purpose. Corporations represent and are authorized by the public, not by their shareholders, nor even their contributors/direct stakeholders. But the public has simultaneously given them the legal tools and hence power to undermine that mandate, and a direct purpose (private gain) which incentivizes them to do so. The normative legitimation structure of both features of the modern business corporation-economic privileges and freedom of incorporation-are in tension with each other, a tension that modern sovereigns will have to navigate before they are overtaken by the power of (multinational) corporations.

\section{The Neo-Hobbesian Concession Theory in the Contemporary Debate}

The neo-Hobbesian position brings new relevance to the supposedly defunct concession theory. In doing so, a neo-Hobbesian theory is similar in spirit to and compatible with the work of other authors reviving concession theory. ${ }^{93}$ To this body of work, the neo-Hobbesian position can add two things.

92. One can question whether this formula of wealth maximization is sufficiently broad, or whether distributive justice considerations need to be added to the formulation of public interests. See Abraham Singer, "Justice Failure: Efficiency and Equality in Business Ethics," Journal of Business Ethics 149 (2018): 97-115.

93. See Bakan, The Corporation; McMahon, Public Capitalism; and Ciepley, "Beyond Public and Private." 
First, an explicit reliance on Hobbes's theory of authorization and representation helps to link the political theory of the corporation to the legitimacy demands of contemporary democratic theory. The neo-Hobbesian theory suggests that the business corporation must be traced back to an authorizing author, and that only the state can fulfill that role. Its authorization in turn goes back to the members of the multitude. The implications of this seem to be that all citizens authorize, or "own," the acts of all corporations, and that corporations represent the citizens, as united in the state. These implications may seem counterintuitive when transposed to today's business corporations. ${ }^{94}$ However, I do think this is how we must see things if we follow Hobbes. As to the language of authorization, we need to remind ourselves that the authorization in question here is a broad one. Corporations can, within their mandate, figure out their particular course of action. As long as their actions stay within the mandate, they thereby fulfill their publicly mandated purpose. Although the public at large never directly authorizes a particular act, it does authorize a range of permissible acts (note that any relation of representation/authorization requires the actor to interpret the mandate given by the author; this interpretation presupposes some discretion in how exactly to fulfill the mandate). As to the language of representation, then, in some sense corporations do represent the public. When the public together decides to open up legal incorporation to ordinary commercial businesses, it sends them off on a special mission: to create social wealth. Businesses represent the public on this mission. This may seem strange, but public cries for accountability when some business scandal has broken out testify to the fact that there is this underlying relation, which defines publicly determined limits to what business corporations can legitimately do.

Second, Hobbes's discussion shows how it is unnecessary and indeed misleading to portray the concession theory as requiring an exclusively public orientation. Through its critical discussion of the merchant companies' monopoly position, the neo-Hobbesian theory provides an opening to introduce ideas of market failure as benchmarks for thinking about public benefit. This helps to establish a dialogue with positions like those of Abraham Singer, ${ }^{95}$ which make use of such ideas to revive real entity theory. How the neo-Hobbesian theory differs from such real entity theories, which also draw on market failure concepts, is a matter for further discussion. ${ }^{96}$ If it is accepted that both allow for private initiative and purpose, the real

94. I thank two reviewers for this challenge.

95. Singer, The Form of the Firm.

96. See note 57 above for one major difference that remains between both theories. 
debate can be moved to the more interesting question of whether the authorizing link of corporations to the state justifies stronger public interest requirements of business corporations than what normal individuals (or partnerships) on the market are subject to. Recently, Singer has argued that the rules of the market, including the rules for unincorporated entities, are also publicly constituted; hence an a priori distinctive treatment for corporations would be unwarranted. ${ }^{97}$ This argument merits future debate.

In closing, let me note two other issues (and surely more issues will have to be added to this list) that deserve special attention if such a view is to become an attractive alternative in a contemporary context. Both of these issues create challenges for both concession theory and for its competitors. Nonetheless, these challenges are especially salient if the legitimacy of corporations is linked so strongly to a chartering state, as in concession theories. One issue is how to judge whether a corporation acts within the bounds of what I have called the special public compatibility requirement. This requires a judgment of public interest in which wealth in a strictly monetary sense is just one component. Hence trade-offs between wealth and other types of interests (e.g., environmental interests, worker interests) connected to corporate performance need to be made. How to make such judgments substantively, and how to create a procedure for states to make these judgments, is far from clear. ${ }^{98}$ A second question is if concession theory can survive the globalization of the economy. If legitimate corporate action hinges on a controlling nation state, how can today's multinationals be legitimate? Wouldn't this require a chartering world sovereign power? ${ }^{99}$ While still being chartered in a national jurisdiction, the national basis may be insufficient to hold corporations to account when much of their operations are spread out across multiple nation states.

These issues are not easily solved. However, Hobbes's treatment of these matters suggests that a link between business corporations and the state remains vital, even when states grant corporations personality for the rather general purpose of social wealth maximization.

97. Abraham Singer, "The Corporation's Governmental Provenance and Its Significance," Economics and Philosophy 35 (2019): 283-306.

98. On the weakness of charter oversight, even historically, see David Ciepley, "Can Corporations Be Held to the Public Interest, or Even to the Law?," Journal of Business Ethics 154 (2019): 1003-18.

99. The title of a well-known volume on multinationals refers to them as the new "Leviathans." See Alfred Jr. Chandler and Bruce Mazlish, eds., Leviathans. Multinationals and the New Global History (Cambridge: Cambridge University Press, 2005). 
R.J.G. (Rutger) Claassen is Professor of Political Philosophy and Economic Ethics at the Department of Philosophy \& Religious Studies of Utrecht University. His research interests include theories of socio-economic justice (especially the capability approach) and normative theories of markets, property, and business corporations. He currently directs a research project funded by the Dutch Research Council (NWO) called "Private Property \& Political Power in LiberalDemocratic Societies," as well as a research project funded by the European Research Council (ERC) on "The Business Corporation as a Political Actor." He can be reached at r.j.g.claassen@uu.nl. 